MCW - 1483

$A E C$ Research and Development Report

\title{
INVESTIGATIONS OF SOME EXPERIMENTAL FUEL ELEMENT ALLOYS \\ WITH THE ELECTRON MICROPROBE
}

\section{April 15, 1964}

\section{WELDON SPRING PLANT}

$$
\begin{aligned}
& \text { MALLINCKFODT CHEMICAL WORKS } \\
& \text { UPANIUM GIVISION } \\
& \text { Gontract No. W-1 } N-10 \beta-E n \varepsilon-\varepsilon
\end{aligned}
$$




\section{LEGAL NOTICE}

This report was prepared as an account of Government sponsored work. Neither the United States, nar the Commission, nor any person acting on behalf of the Commission:

A. Makes any warranty or representation, expressed or implied, with respect to the occuracy, completeness, or usefulness of the information contained in this report, or that the use of any information, apparatus, method, or process disclosed in this report may not infringe privately owned rights; or

B. Assumes any liabilities with respect to the use of, or for damages resulting from the use of any information, apparafus, method, or process disclosed in this report.

As used in the above, "person acting on behalf of the Commission" includes any employes or contractor of the Commission, or employee of such contractor, to the extent that such employee or eontractor of the Commission, or employee of such contractor propares, disseminates, or provides access to, any information pursuant to his employment or contract with the Commission, or his employment with such contractor.

Printed in USA. Price $\$ 0.50$ Available from the Office of Technical Services, Department of Commerce, Washington 25, D.C. 


\section{DISCLAIMER}

This report was prepared as an account of work sponsored by an agency of the United States Government. Neither the United States Government nor any agency Thereof, nor any of their employees, makes any warranty, express or implied, or assumes any legal liability or responsibility for the accuracy, completeness, or usefulness of any information, apparatus, product, or process disclosed, or represents that its use would not infringe privately owned rights. Reference herein to any specific commercial product, process, or service by trade name, trademark, manufacturer, or otherwise does not necessarily constitute or imply its endorsement, recommendation, or favoring by the United States Government or any agency thereof. The views and opinions of authors expressed herein do not necessarily state or reflect those of the United States Government or any agency thereof. 


\section{DISCLAIMER}

Portions of this document may be illegible in electronic image products. Images are produced from the best available original document. 
MCW-1483

UC-25, Metals, Ceramics, and Materials

(TID-4500, 28th Edition)

TOPICAL REPORT

INVESTIGATIONS OF SOME EXPERIMENTAL FUEL ELEMENT ALLOYS

WI TH THE ELECTRON MICROPROBE

by

L. A. Fergason

D. L. Parker

N. F. Neumann

April 15, 1964

Mallinckrodt Chemical Works

Uranium Division

Weldon Spring, Missouri 
DISTRIBUTION

Number of Copies

Internal

22

External in accordance with TID-4500, 28th Edition

Category UC-25, Metals, Ceramics, and Materials

Special

American Radiator and Standard Sanitary Corporation

Bureau of Mines, Reno

Mr. T: R. Graham

Cinclinnati Area office

Mr. C. L. Kar1

Division of Production, Washington

Mr. W. Devine

Dow Chemical Company, Rocky Flats

Dr. L. A. Matheson

General Electric Company, Richland

Mr. R. S. Kemper

Mr. G. A. Last

Dr. J. E. Minor

Oak Ridge Operations office

Mr. E. B. Kiser, Jr.

Mr. B. M. Robinson

Dr. R. E. Wedemeyer 
\begin{tabular}{l} 
INVESTIGATIONS OF SOME EXPERIMENTAL FUEL ELEMBNT ALLOYS \\
WITH THE ELECTRON MICROPROBE \\
\hline
\end{tabular}

by

L. A. Fergason

D. L. Parker

N. F. Neumann

\section{ABSTRACT}

The microstructures of seven alloys were investigated with the Cambridge microprobe. Six of the alloys were uranium containing the following combinations of other elements:

$\mathrm{S} ; \mathrm{P} ; \mathrm{Zr}, \mathrm{Fe}$, and $\mathrm{Al} ; \mathrm{Zr}$ and $\mathrm{P} ; \mathrm{Fe}$ and $\mathrm{SI}$; and $\mathrm{A} 1, \mathrm{Fe}$, and si. One was a section of a thorium fuel element. 
INVESTIGATIONS OF SOME EXPERIMENTAL FUEL ELEMENT ALLOYS WITH THE ELECTRON MICROPROBE

by

L. A. Fergason

D. L. Parker

N. F. Neumann

\section{INTRODUCTION}

The alloys of uranium and thorium, because of their varied physical and chemical characteristics, are under investigation at many AEC sites for their potential utility as fuel elements. Integral to the understanding of these alloys is the nature of their microstructures and phase relationships. These microstructures are revealed metallographically and may be characterized by classical techniques. The scanning electron microprobe is a powerful adjunct to these techniques in the identification and quantitative determination of micro-inclusions.

An extensive program is under way at the MCW Weldon Spring site employing the microprobe in uranium alloy studies. Specimens representing seven alloys prepared at the Hanford Atomic Products Operation were submitted for investigation with the Cambridge Mark II Microscan X-ray Analyzer. Six of these samples were alloys of uranium and one of thorium.

Metallographs taken at HAPO were submitted with the samples and used to aid in developing maximum information from phase identification with the probe. While detail is lost in reproduction, halftone copies are included here for ease of demonstrating the relationships observed.

GENERAL CONSIDERATION

The Cambridge microprobe used in this investigation was of conventional design and has been adequately described elsewhere, 1,2

Preparatory to analysis, the samples were mounted in conductive bakelite and diamond polished. Standard etching procedures were used, where necessary, for metallographic examination and qualitative identification of inclusions with the microprobe. For quantitative analysis, a very light etch was given in those cases necessary to remove metal smear; otherwise, none was used at al1. If possible, etching is to be avoided before quantitative analysis because etching causes the various inclusions, matrix, and standards to be left in comparative relief. This difference in level of the specimen surface tends to change the focusing characteristics of the spectrometer. It is also important to avoid valleys and ridges because they may change the effective $X$-ray take-off angle, thus changing the self-absorption and secondary fluorescence effects. Finally, by its very nature the chemical etch may 
preferentially remove different elements leaving a surface which is not chemically representative of the whole.

Two methods of quantitative analysis were used. One was of the conventional technique of comparing the characteristic X-ray emission of an element in the alloy with that of the pure element. Corrections for atomic number effects and self-absorption were usually made according to the method of Poole and Thomas $^{4}$ and are described in a previous report. ${ }^{2}$ Backscatter analysis was also performed on some of the inclusions and, as the name implies, was performed by measuring the quantity of electrons rejected or backscattered from the surface of the alloy. The magnitude of this backscattering is related to the average atomic number $(\bar{Z})$ of the area being measured.

The analysis was conducted by measuring (1) the total probe current with the aid of a Faraday cage in a sample mount position, (2) the residual sample current (after backscatter) in the alloy $A B$, and finally (3) the sample current of each of the pure elemental components $A$ and $B$.

The backscatter coefficient, $r$, was then determined for each of the measurements by the following formula: ${ }^{4}$

$$
r=\frac{\text { probe current }- \text { specimen current }}{\text { probe current }}
$$

The concentration, $C_{A}$, was calculated from the following formula:

$$
r_{A B}=C_{A} r_{A}+\left(1-C_{A}\right) r_{B}
$$

where $r_{A B}, r_{A}$, and $r_{B}$ are backscatter coefficients of the alloy and each of the pure components, respectively.

The sample current measurements were taken with a Kiethely electrometer across a $100 \mathrm{~K}$ resistor.

EXPERIMENTAL PROCEDURE AND RESULTS

Sample No. 1

The first sample to be investigated was thorium alloyed with $2.5 \mathrm{wt}$. $\% \mathrm{U}$ and 1 wt. \% $\mathrm{zr}$, coextruded with zircalloy -2 at $760^{\circ} \mathrm{C}$ with a reduction ratio of $17: 1$, and vacuum heat-treated for one hour at $750^{\circ} \mathrm{C}$. Included with this sample was a thorium metal base stock specimen (Figures 1 and 2 , respectively).

These samples were mounted together in a conductive bakelite mold suitable for probe analysis. Most of the observations were made on as-diamondpolished surfaces. Correlation of inclusions identified with the microprobe and inclusions as shown on the original metallographs were sometimes uncertain. For this reason, this specimen was polished and etched according to the recommendations of $\mathrm{Mr}$. Rodger Todd of Hanford for some qualitative observations 


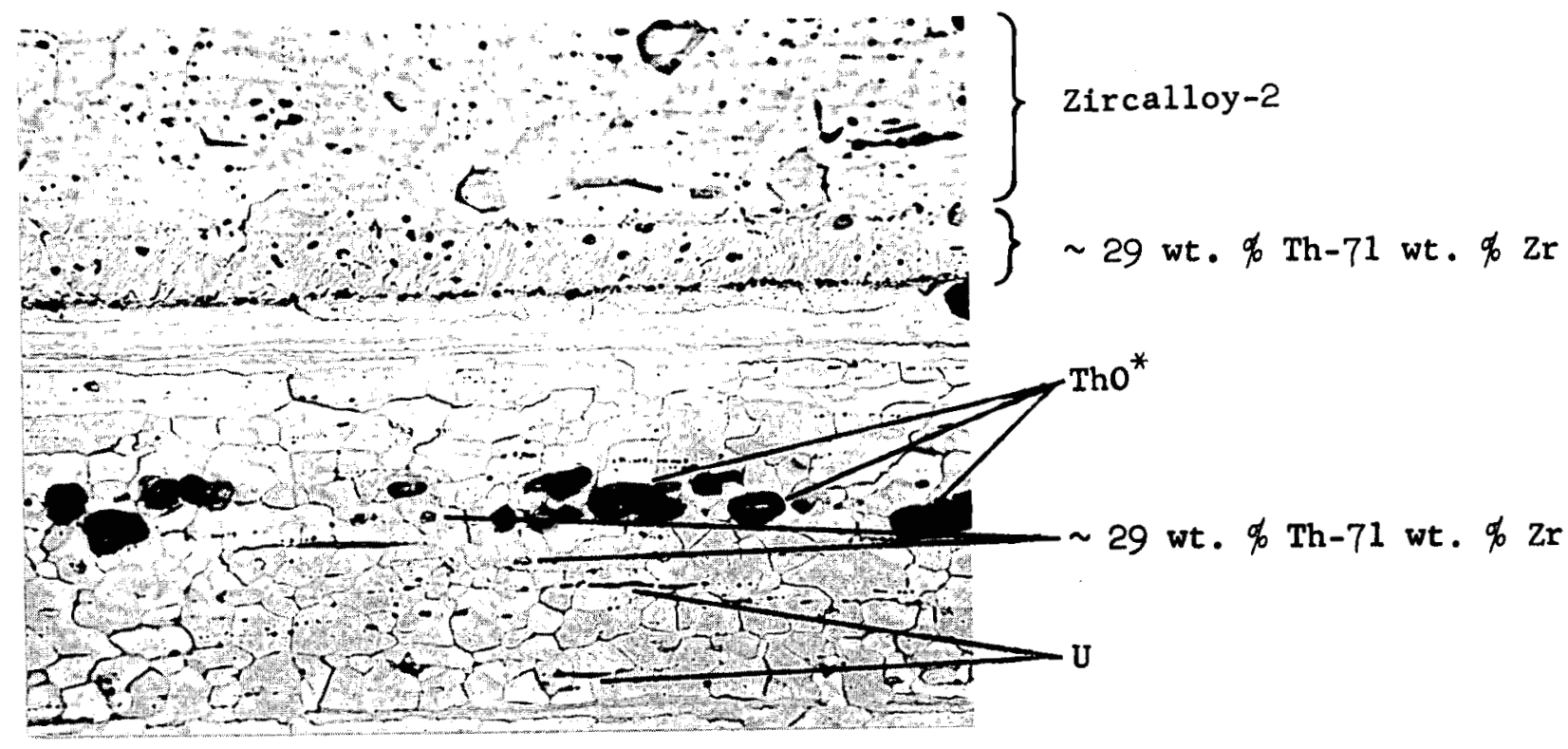

Figure 1. Sample 1. Thorium Alloyed with 2.5 wt. $\% \mathrm{U}$ and 1 wt. $\% \mathrm{Zr}$ Coextruded with Zircalloy-2. 500X. (HAPO Neg. 4W-63-285B)

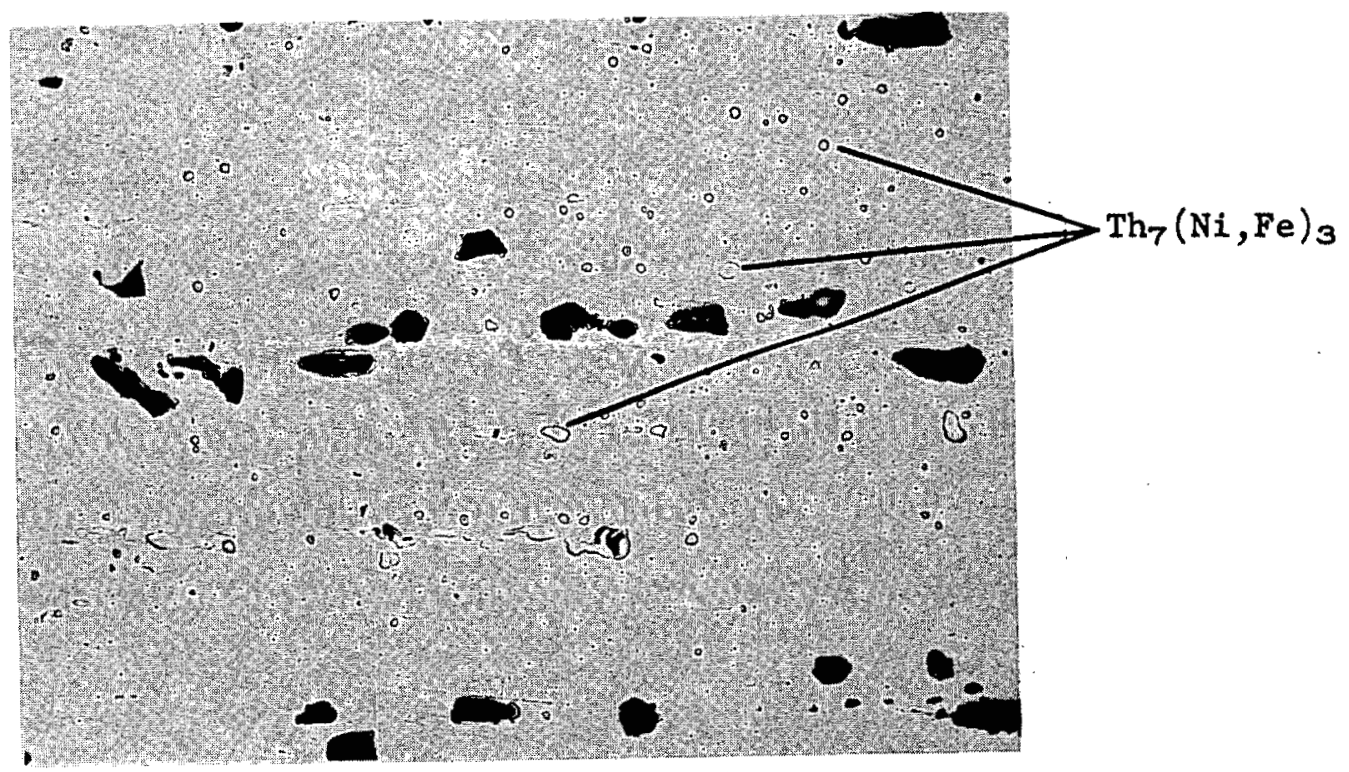

Figure 2. Thorium Metal Base Stock Used in Preparation of Sample 1. 250X. (HAPO Neg. '4Z-1862)

${ }^{*}$ See text. 
In the probe. Accordingly, the sample was polished with a l $\mu$ alumina abrasive (Linde "A," Linde Alr Products Co.) in a liquid soap vehicle and electrolytically etched in an alcohol-perchloric acid bath at 25 volts for 10 seconds.

The chemical nature of the zircalloy-2-thorlum bond layer was studied by traversing the electron beam slowly across the bond concurrently with the recording of $\mathrm{Th} \mathrm{L} \alpha$ and $\mathrm{Zr} K \alpha \mathrm{X}$-ray emlssion intensities. A concentration plateau about $10 \mu$ wide was observed between the can and core. Subsequent electron backscatter analysis showed the plateau ta be $71-72$ wt. $\%$ $2 r$ in Th.

These results coincide within the limits of error of an eutectold composition of $69.5 \mathrm{wt}$. क $\mathrm{Zr}$ reported by Carlson, $5,6,7$ The various inclusions in the canned core metal and the base stock thorlum were identified and the results are presented as follows:

Metall1c uranium was seen to be present in the long strata-1ike inclusions and some of the smaller round inclusions found in the stringers (see Figure 1).

The large black inclusions tentatively identifled as Tho by Hanford could not be positively identified with the microprobe other than to say that they were thorlum containing. The refractory nature of these inclusions caused a surface charge to be bullt up when they were subjected to bombardment with the electron beam. Consequent1y, the electron beam would be repelled and become unstable, thus precluding any possibility of an accurate $X$-ray analysis without depositing a conductive layer on the surface of the sample. Obviously, electron backscatter analysis could not be effected under these conditions.

A scan of the specimen for $\mathrm{Zr} \mathrm{K} \alpha \mathrm{X}$-ray emission showed areas of high $\mathrm{Zr}$ concentration similar in appearance to those inclusions indicated in Figure 1. Both backscatter and Th X-ray analysis of several of these inclusions again showed a concentration of about $71 \mathrm{wt}$. \% $\mathrm{zr}$. Th1s corresponds to an atomic ratio of $6: 1$ for $\mathrm{zr}$ and Th, respectively.

Inclusions of a Th-Fe-Ni complex were seen in the stock metal as indicated in Figure 2. Similar inclusions could not be located in the fuel element sample, although indications of $\mathrm{Ni}$ and Fe rich areas were detected that were too small to be resolved with the microprobe. The relative intensity of the $\mathrm{N} 1 \mathrm{~K} \alpha$ and $\mathrm{Fe} \mathrm{K} \alpha \mathrm{X}$-ray emissions was about 5 to 1 , respectively. This ratio must be applied to relative concentrations with a degree of caution. The mass absorption coefficient of Fe for $\mathrm{N} 1 \mathrm{~K} \alpha$ radiation is much higher than for the converse and, in turn, iron is strongly fluoresced by $\mathrm{Ni} K \alpha$ radiation. The appearance of these elements in a thorium matrix reduces the magnitude of these interatomic effects but at the same time complicates the correction procedures. All things considered, to assume that the as-measured intensity ratio is equal to the concentration ratio is as 
good a data treatment as any other. At any rate, the tendency would be for the $\mathrm{Fe} K \alpha \mathrm{X}$-ray intensity to be high and the $\mathrm{Ni} \mathrm{K} \alpha$ to be low relative to true concentration.

Analysis of several of these areas by electron backscatter analysis gave an average thorium concentration of $90.9 \mathrm{wt} . \%$. This value agrees closely with the theoretical values of $90.2 \mathrm{wt} . \%$ Th in $\mathrm{Th}_{7} \mathrm{Ni}_{3}$ and $90.7 \mathrm{wt}$. \% Th in $\mathrm{Th}_{7} \mathrm{Fe}_{3}$ and is compatible with intermetallic compounds as shown in published phase diagrams. 7

Sample No. 2

This sample was uranium containing about $5000 \mathrm{ppm}$ sulfur. This alloy was prepared by arc casting a button with dingot uranium feed stock and sulfur added as US. The button was heated four hours at $800^{\circ} \mathrm{C}$ and slowly cooled. Figures $3 a$ and $b$ are metallographs of this alloy prepared by Hanford. Analyses of the structure revealed the following:

The sample was a uranium-sulfur alloy. Figure 4 is a backscatter image taken of the as-diamond-polished surface. The dark, lower atomic number areas were determined to contain sulfur.

Uranium X-ray analysis of these areas resulted in an average value of $86 \mathrm{wt}$. \% U after correction for absorption and atomic number effects.

Backscatter analysis of the same areas gave a value of 89.5 wt. \% U. The analytical technique for the backscatter analysis was the same as described previously for Sample No. 1 except the $r$ value for sulfur had to be extrapolated from values measured for $\mathrm{Mg}, \mathrm{Al}$, and Si. The results of these analyses most closely fit the stoichiometry of US which is $88.2 \mathrm{wt}$. \% $\mathrm{U}$.

The eutectoid structure shown in the dark field picture (Figure $3 \mathrm{~b}$ ) could not be seen in the X-ray or backscatter images obtained with the microprobe. The probe diameter was about $0.5 \mu$ when the attempt was made. An ortho-phosphoric acid etch failed to assist in revealing this structure.

Sample No. 3

Sample 3 was $U$ containing about 2700 ppm P prepared by arc casting. This sample exhibited four types of microstructure when investigated with the microprobe (see Figures 5 and 6 ). They were as follows:

Large angular inclusions containing phosphorus in quantity equal to that of UP were seen. Figures $7 a$ and $b$ show backscatter and $P \mathrm{~K} \alpha$ $X$-ray images, respectively, of areas containing this type of inclusion. 


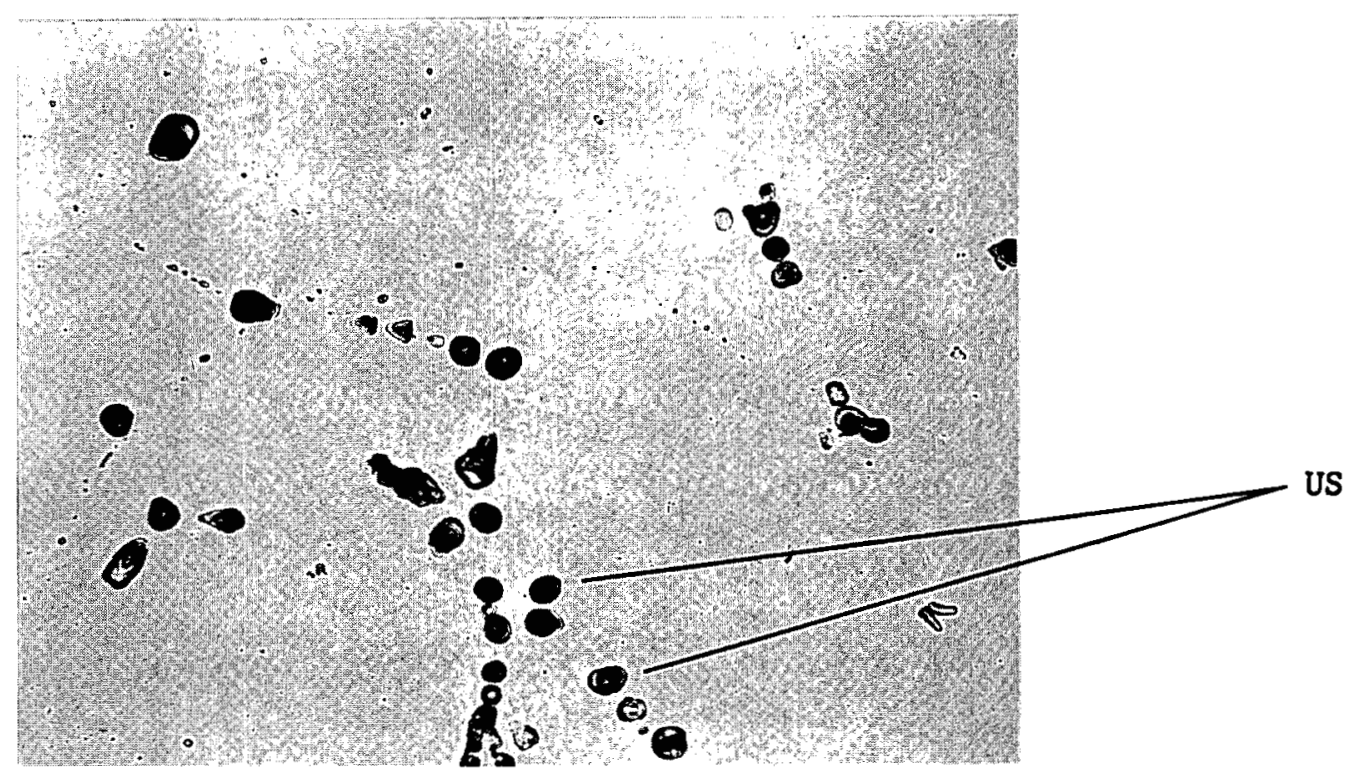

a) Brightfield 500X. (HAPO Neg. 4Z-1651B)

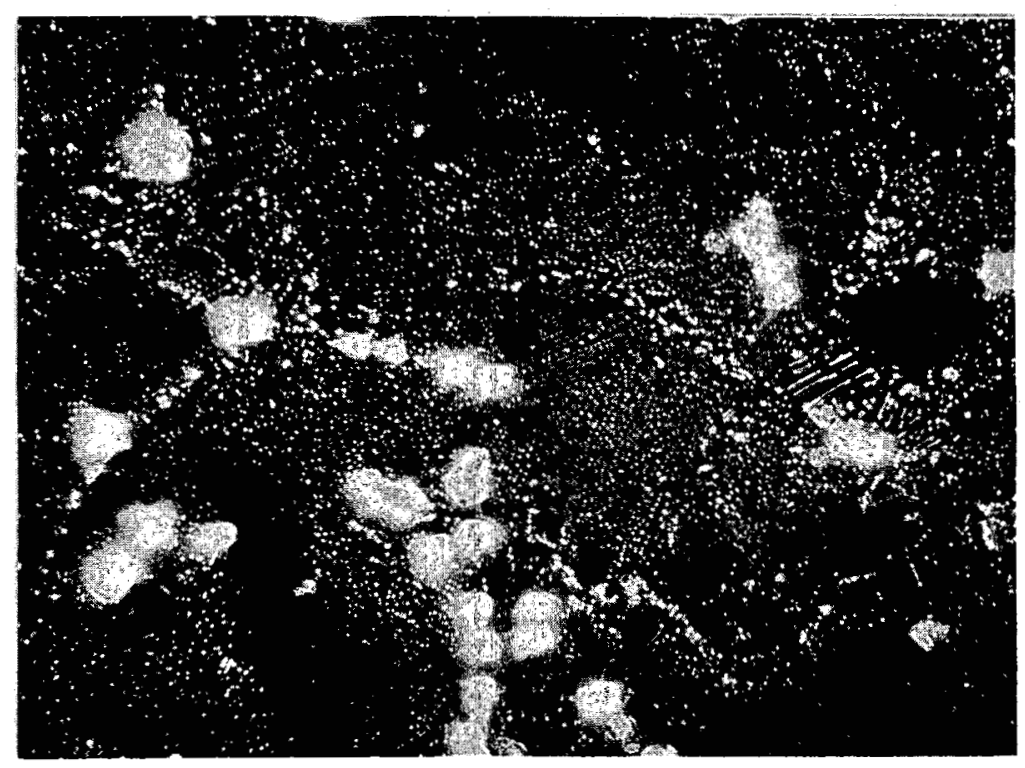

b) Darkfield 500X. (HAPO Neg. 4Z-1651A)

Figure 3. Sample 2. Uranium with 5000 ppm Sulfur. 


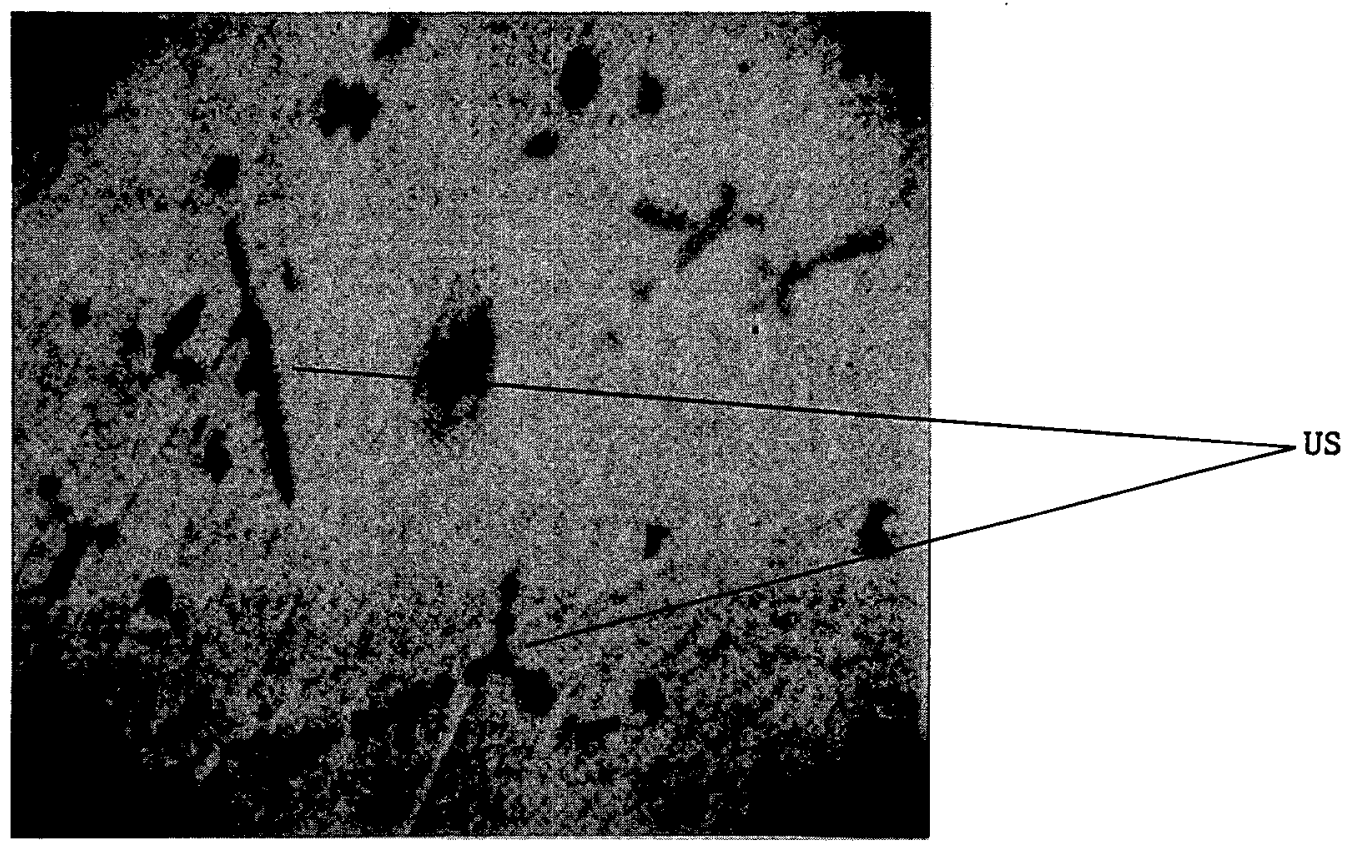

Figure 4. Sample 2. Electron Backscatter Image. 500x. 


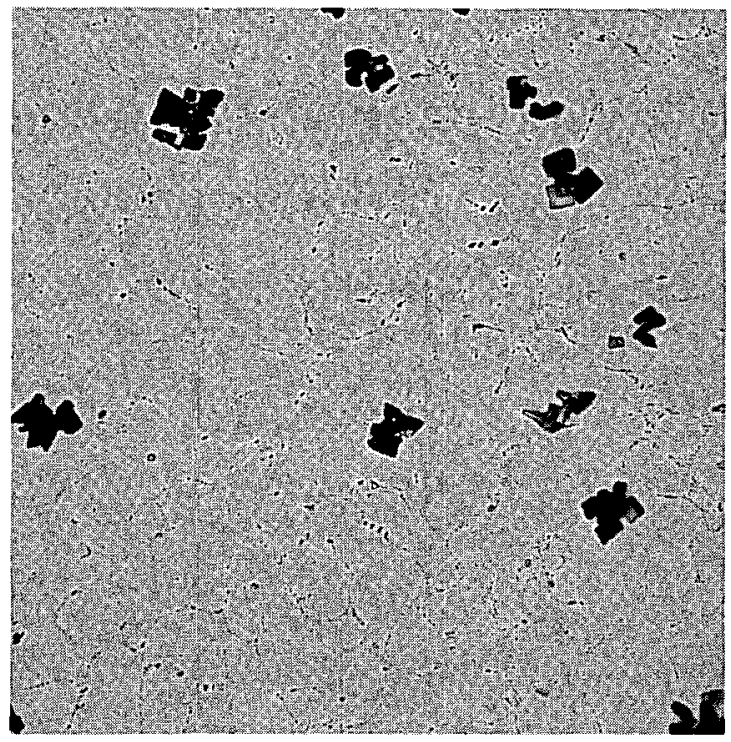

Figure 5. Sample 3. Uranium with $2700 \mathrm{ppm}$ Phosphorus. 500x. (HAPO Neg. 4Z-1628B)

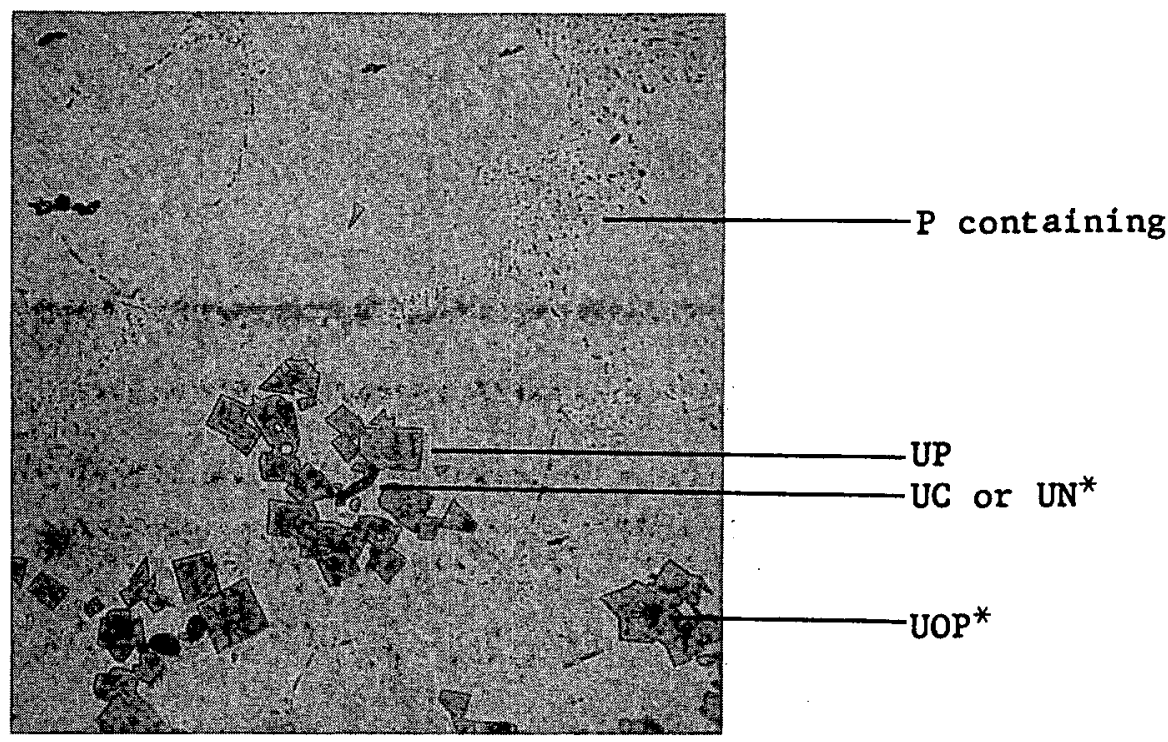

Figure 6. Sample 3. MCW Metallograph. 750X.

*See text. 


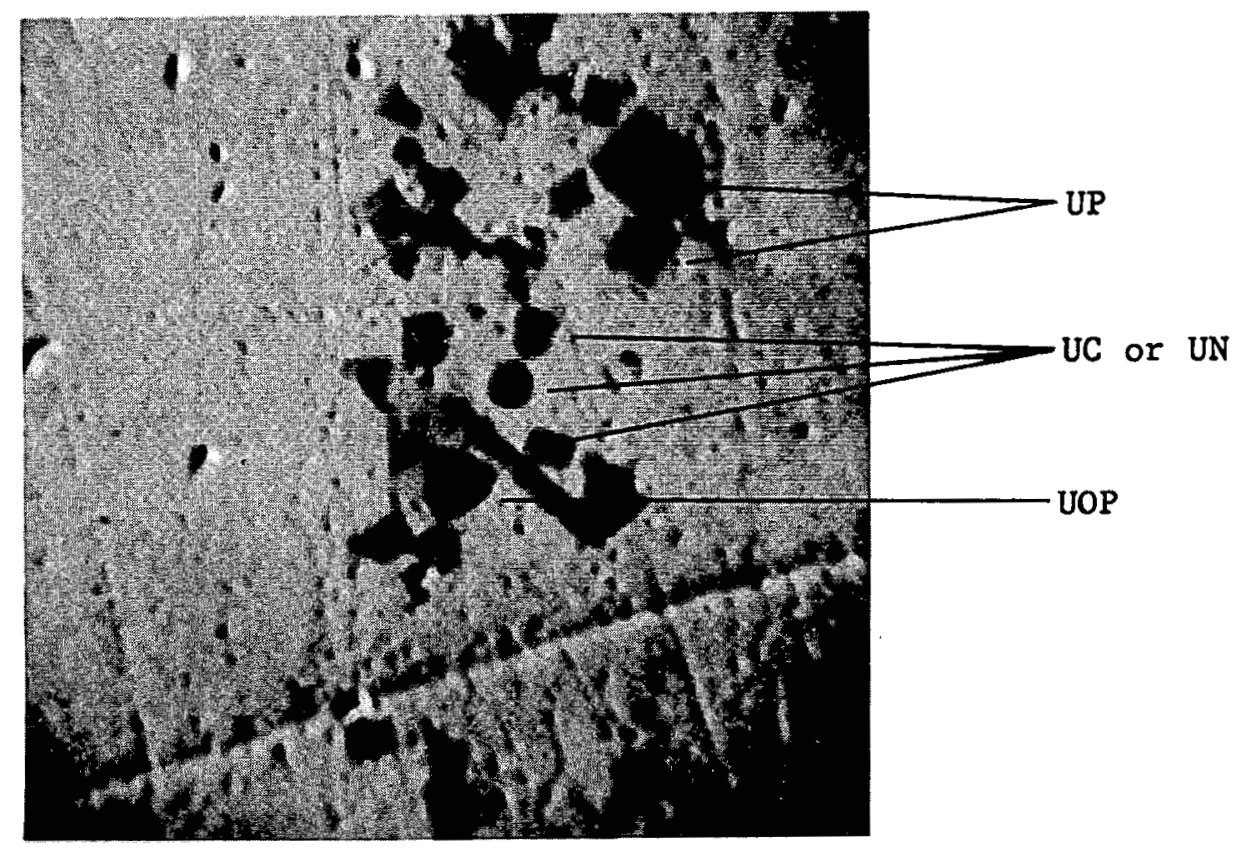

a) Electron Backscatter Image. 750X.

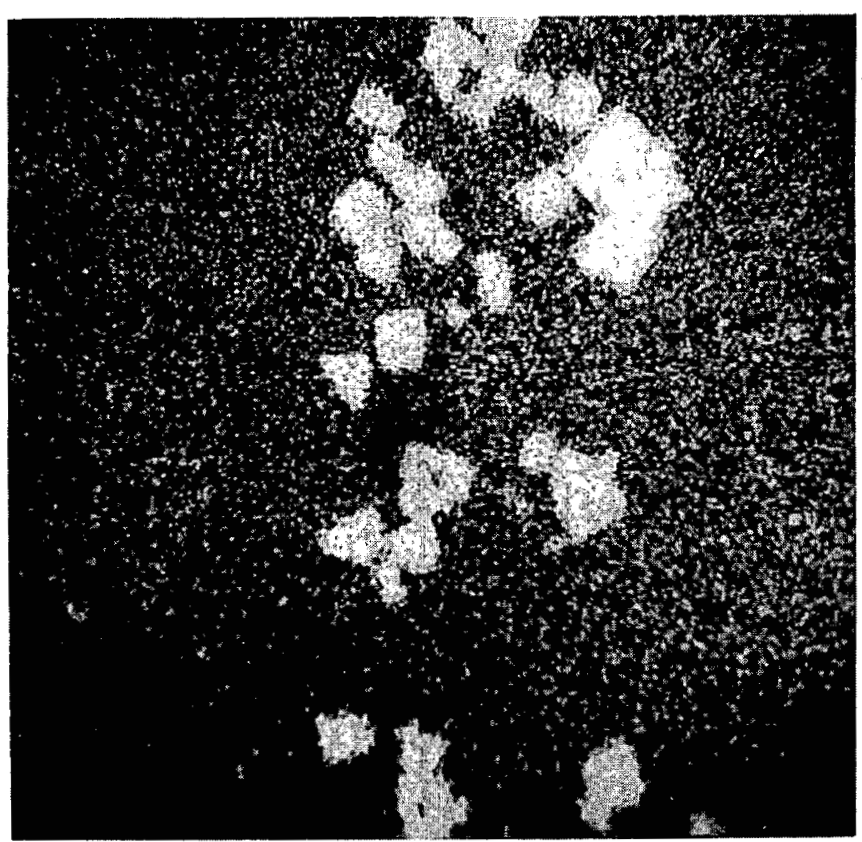

b) P Ka X-ray Image. $750 \mathrm{x}$.

Figure 7. Sample 3. Images of Uranium-Phosphorus Alloy Taken from Microprobe. 
Other phosphorus inclusions, fewer in number and containing less phosphorus than UP, approached the concentrations expected for UOP.

The large non-phosphorus containing inclusions shown in Figures $7 a$ and $b$ probably were uranium carbide or nitride. They contained approximately $95 \mathrm{wt}$. क $U$ as determined by $U$ La X-ray emission. The 1 imits of error of this analysis encompasses the uranium content of both UC and UN; therefore, positive identification could not be made. No other elements were found in the inclusions.

The eutectold-1ike area contained phosphorus; however, quantitative analysis was not possible. The $X$-ray analytical area was two to three microns in diameter which was greater than the size of the inclusions; consequently, only qualitative analyses could be made.

Sample No. 4

This uranium alloy contained 1 wt. $\% \mathrm{zr}, 200 \mathrm{ppm} \mathrm{Fe}$, and $350 \mathrm{ppm} \mathrm{Al.} \mathrm{Prior}$ to examination, the arc-cast button was heated for three days at $800^{\circ} \mathrm{C}$ and then water quenched. This treatment was followed by a 100 -hour anneal at $600^{\circ} \mathrm{C}$ from whlch temperature the sample was furnace cooled. Figures $8 a$ and b and Figure 9a are photomicrographs showing the structure. The sample was diamond polished and then given a light ortho-phosphoric acid etch. Microprobe analyses gave the following results:

Figure $9 b$ is an electron backscatter image of the same area as seen In Figure $9 a$ with some of the inclusions identifled. The light inclusions in relief on the backscatter pattern are $U_{6} F e$. For the most part, the $U_{B} \mathrm{Fe}$ was randomly distributed; however, some subnetwork structure is made up of very small $\mathrm{U}_{6} \mathrm{Fe}$ inclusions.

The small gray areas, found mostly in the major network, are $\mathrm{UAl}_{2}$.

The larger dark inclusions are $2 \mathrm{rC}$.

Quantitative analysis of the $\mathrm{UAl}_{2}$ and $\mathrm{U}_{6} \mathrm{Fe}$ was achieved by comparing the $\mathrm{Al}$ and $\mathrm{Fe} \mathrm{K} \alpha \mathrm{X}$-ray intensities to that of the known intermetalifcs of these species.

The $\mathrm{Zr} L \alpha$ emission from the $\mathrm{ZrC}$ areas was compared with that of pure $\mathrm{Zr}$. No uranium could be detected in these inclusions.

Sample No. 5

Uranium was arc cast with 1 wt. $\% \mathrm{zr}$ and $350 \mathrm{ppm} P$. The sample was annealed three days at $800^{\circ} \mathrm{C}$, water quenched, annealed 100 hours at $600^{\circ} \mathrm{C}$, and furnace cooled. 


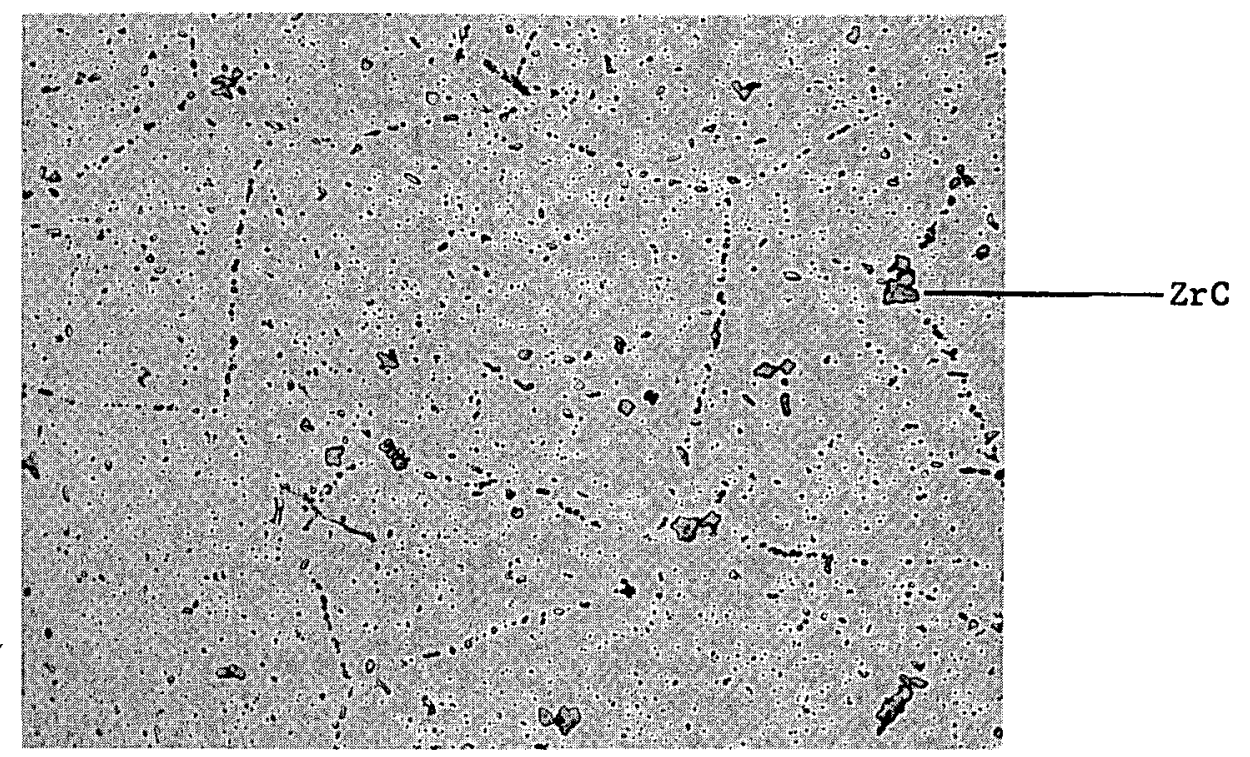

a) 500X. (HAPO Neg. 4Z-1669B)

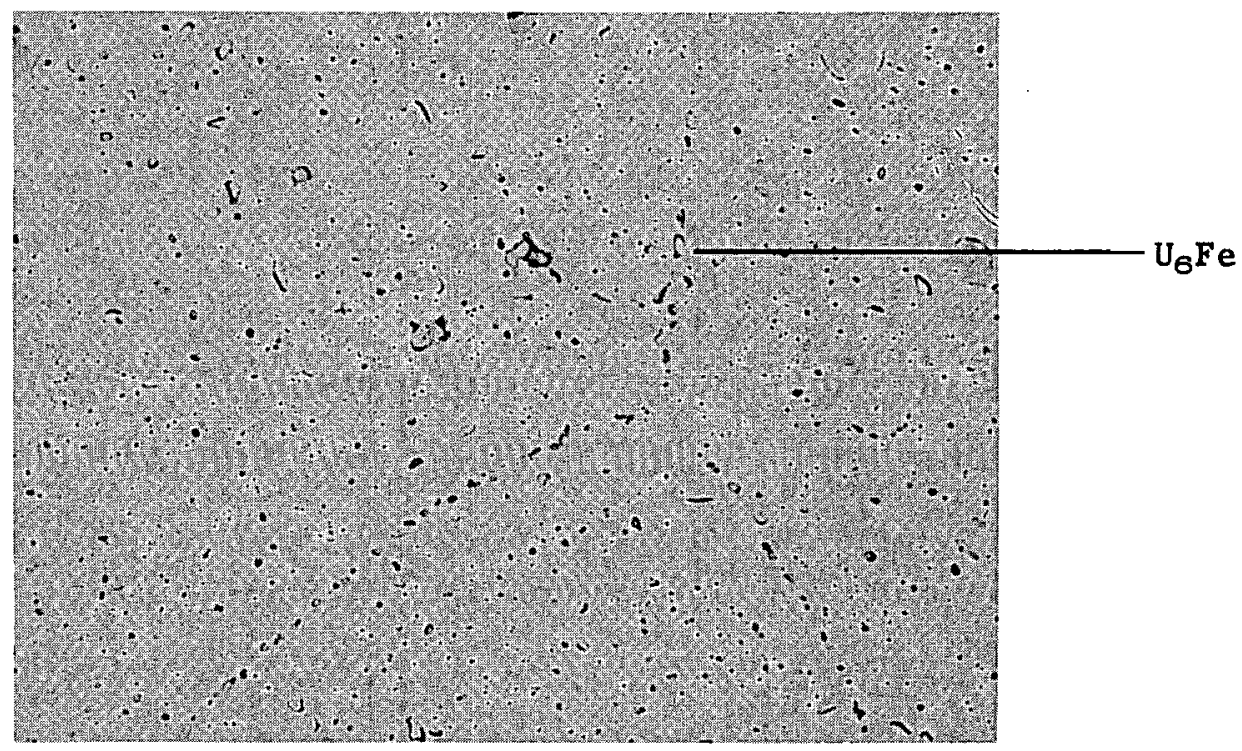

b) 1000X. (HAPO Neg. 4Z-1669C)

Figure 8. Sample 4. Uranium with 1 wt. $\% \mathrm{Zr}, 200 \mathrm{ppm} \mathrm{Fe}$, and $350 \mathrm{ppm} \mathrm{Al}$. 


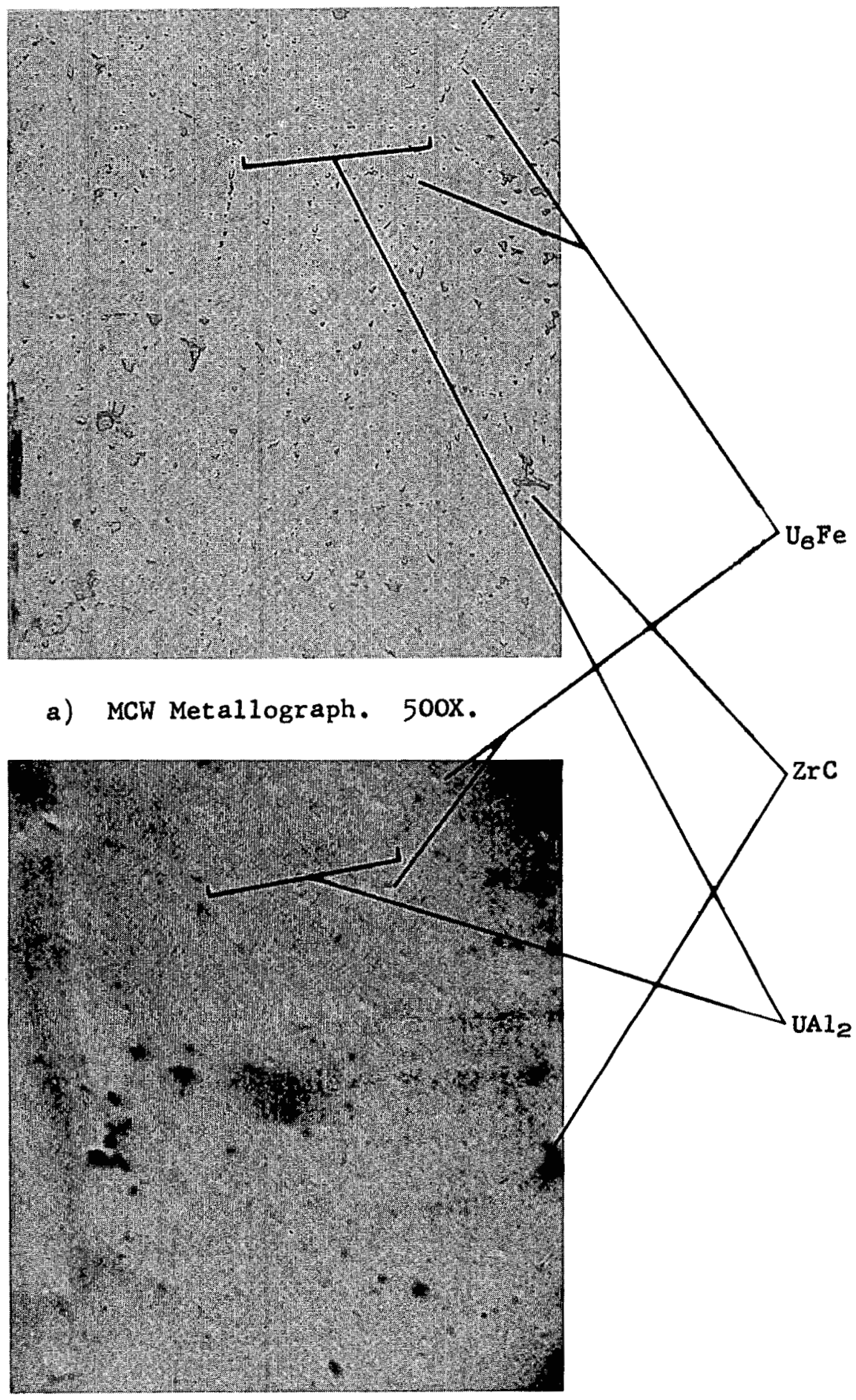

b) Backscatter. 500x.

Figure 9. Sample 4. Comparison of Metallograph with that of Backscatter Image. 
The inclusions indicated on the photomicrographs (Figures 10a and $b$ ) contaln $\mathrm{Zr}$ and $\mathrm{U}$, with $\mathrm{P}$ as a minor constituent. No $\mathrm{Zr}$ or $\mathrm{P}$ Inclusions were found without the presence of the other element. Quantitative analysis was not attempted on these inclusions. Phosphorus, zirconium, and uranium together present a special problem in quantitative analysis. 2 irconium $k \alpha$-radiation is interfered with by $U L B$ X-radiation, and the $\mathrm{Zr} L \alpha$ and $\mathrm{P} \mathrm{K \alpha}$ lines interfere with each other. The presence of $P$ and $\mathrm{Zr}$ together in the inclusions was determined by scanning with the gypsum crystal spectrometer in the region of $\mathrm{Zr} L \alpha$ and $\mathrm{P} \mathrm{K \alpha}$ emissions. The resolution of the spectrometer was fully adequate for qualitative analysis.

Sample No. 6

An alloy of uranium containing $130 \mathrm{ppm}$ Fe and $107 \mathrm{ppm}$ S1 was beta heattreated and held at $400^{\circ} \mathrm{C}$ for 72 hours.

The inclusions identified as $U_{G} F e$ are shown in Figure 11 . Silicon containing inclusions could not be detected; however, $\mathrm{U}_{3} \mathrm{Si}$ inclusions in a uranium matrix are difficult to detect with the microprobe if they are less than 0.5 micron in diameter.

Sample No. 7

Th1s beta-treated sample containing uranium with $640 \mathrm{ppm} \mathrm{A1,} 400 \mathrm{ppm} \mathrm{Fe,}$ and $85 \mathrm{ppm} \mathrm{S1}$ was held 24 hours at $600^{\circ} \mathrm{C}$ and furnace cooled.

As shown in Figure 12, the larger inclusions are $\mathrm{U}_{6} \mathrm{Fe}$ areas containing $\mathrm{S} 1$.

Neither $\mathrm{U}_{3} \mathrm{Si}$ nor $\mathrm{UAl}_{2}$ could be resolved. 


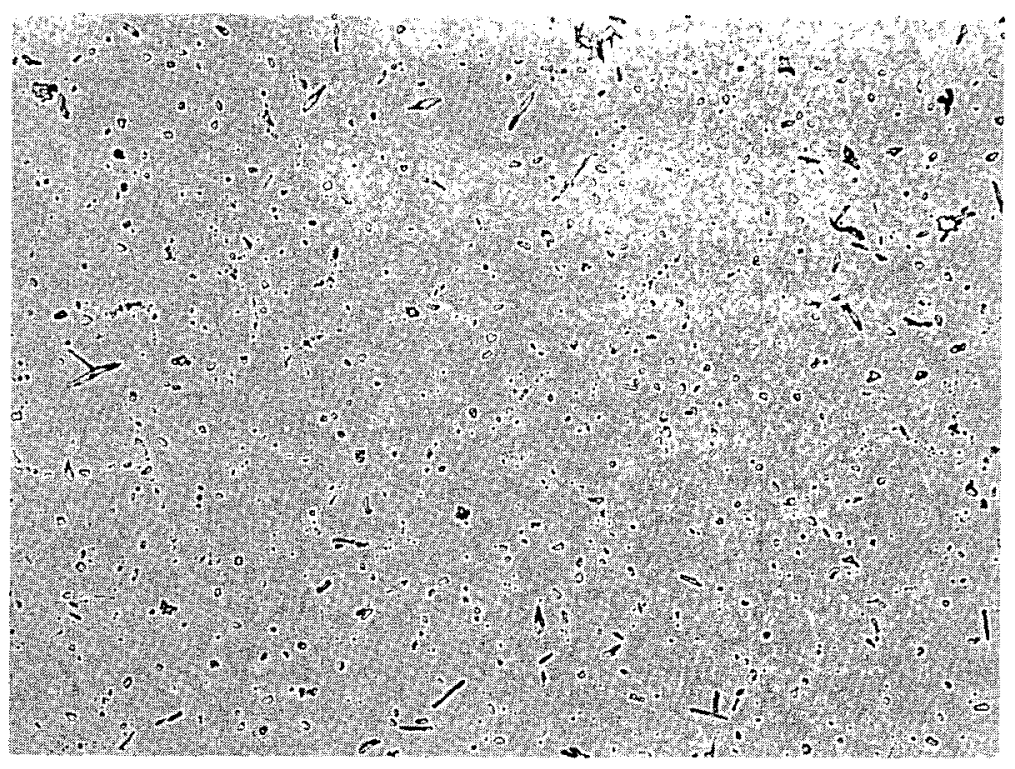

a) 500x. (HAPO Neg. 4Z-1667A)

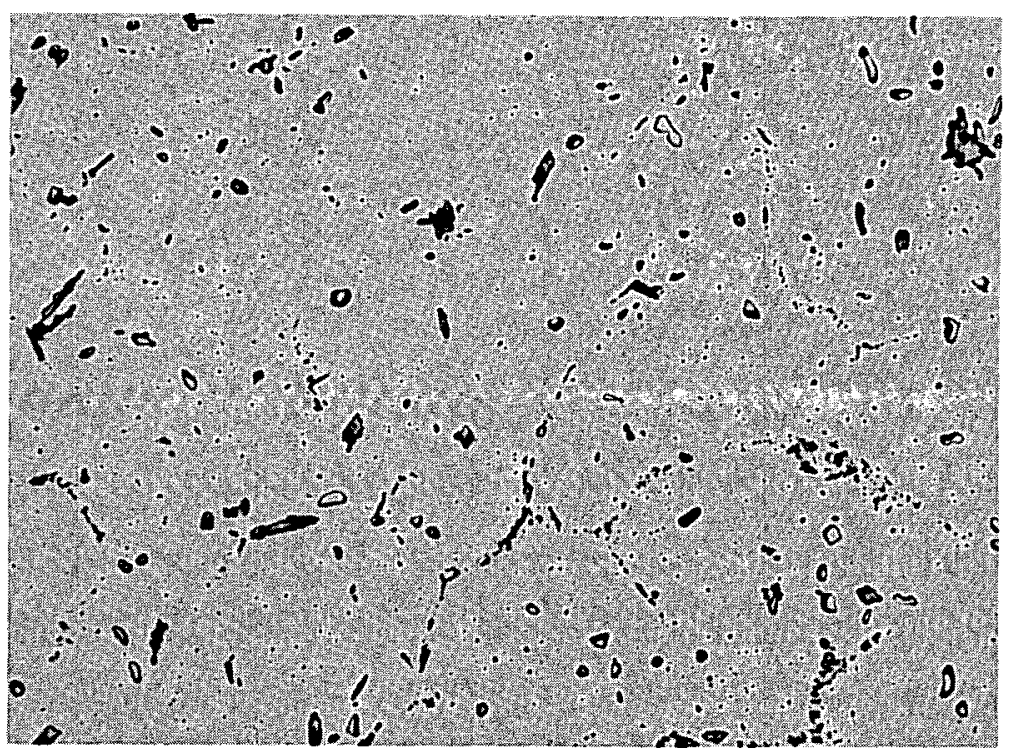

b) 1000x. (HAPO Neg. 4Z-1667B)

Figure 10. Sample 5. Uranium with 1 wt. $\% \mathrm{Zr}$ and $350 \mathrm{ppm} \mathrm{P}$. 


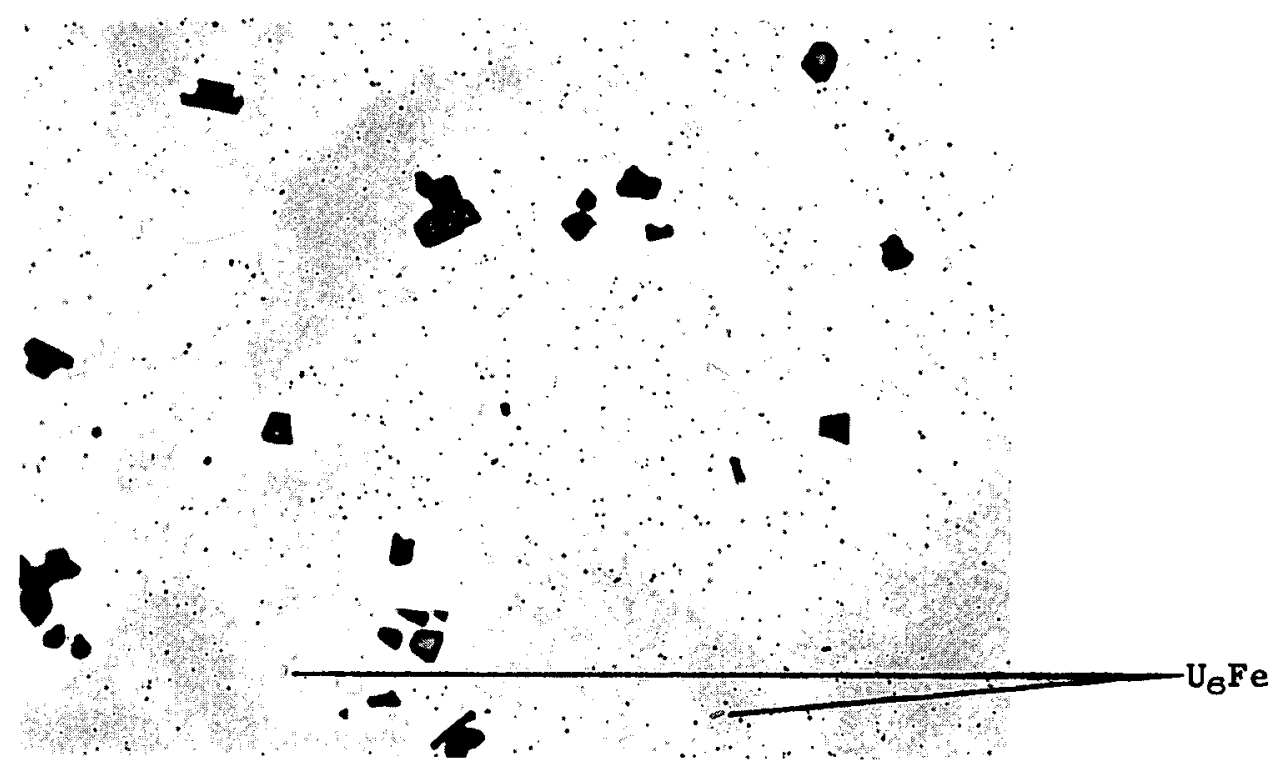

Figure 11. Sample 6. Uranium with $130 \mathrm{ppm} \mathrm{Fe}$ and $107 \mathrm{ppm} \mathrm{Si}$. 500X. (HAPO Neg. 4Z-1749B)

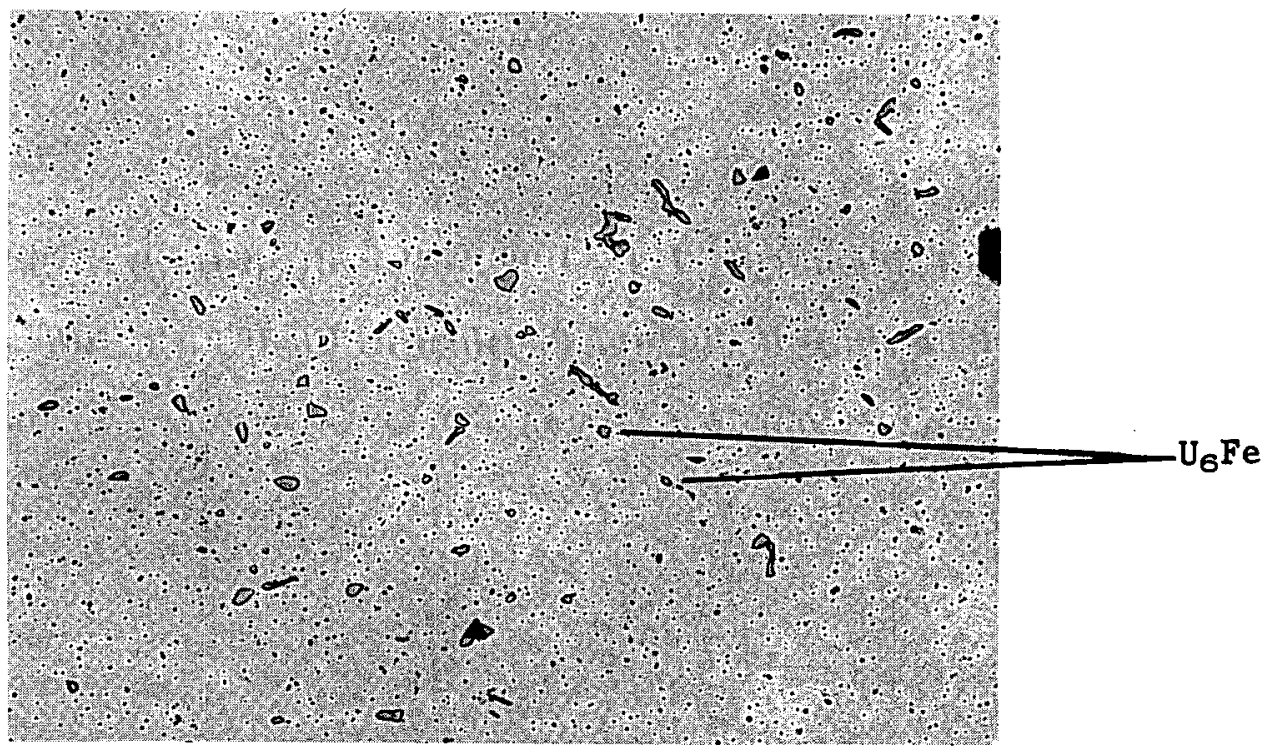

Figure 12. Sample 7. Uranium with $640 \mathrm{ppm} \mathrm{A1,} 400 \mathrm{ppm} \mathrm{Fe}$, and $85 \mathrm{ppm} \mathrm{Si}$. 500X. (HAPO Neg. 4W-62-2276C) 


\section{References}

1. Duncumb, P., Brit. J. Appl. Phys. 10, 420 (1959).

2. Fergason, L. A., and Parker, D. L., Process Development Quarterly Progress Report, Mallinckrodt Chemical Works, MCW-1482 (November 1, 1963), p. $27-35$.

3. Birks, L. S., "Electron Probe Microanalysis," Interscience Publishers, Inc., New York (1963), p. 108.

4. Poole, D. M., and Thomas, P. M., "Quantitative Electron-Probe Microanalysis," Atomic Energy Research Establishment, Metallurgy Division, Harwel1, Berkshire, England, AERE R-3815 (1961).

5. Carlson, 0. N., "Some Studies on the Uranfum-Thorium-Zirconium Ternary Alloy System," Ames Laboratory, Iowa State College, AECD-3206 (June 5, 1950).

6. Gibson, E. D., Loomis, B. A., and Carlson, 0. N., Trans. Am. Soc. Metals 50, 348 (1958).

7. Rough, F. A., and Bauer, A. A., "Constitutional Dlagrams of Uranium and Thorlum Alloys," Addison-Westley Publishing Company, Inc., Reading, Mass. (1958). 